\title{
ESTIMATION OF THE CONTRIBUTIONS OF CONDUCTANCE AND ELECTRIC FIELD TO THE INTENSITY OF FIELD-ALIGNED CURRENTS IN THE NIGHT POLAR IONOSPHERE DURING SUBSTORM EXPANSION PHASE
}

\author{
V. V. Mishin, S. B. Lunyushkin, V. M. Mishin, \\ M. A. Kurikalova, Yu. V. Penskikh \\ Institute of Solar-Terrestrial Physics, Siberian Branch of RAS, Irkutsk, Russia
}

\begin{abstract}
Based on the output data of the magnetogram inversion technique, we analyze the dynamics of the Pedersen ionospheric currents and field-aligned currents (FACs) in the night mesoscale cells of the three main large-scale Iijima and Potemra Regions (R1, R2 and R0) during the expansion phase of the summer and winter substorms. FACs play a key role in the ionosphere-magnetosphere interaction. The continuity equation for the electric current density contains two types of possible feedback within the electric circuit parts that connect Pedersen currents and FACs in each cell. Pedersen ionospheric conductivity is dominant to Type 1, and the electric field dominates in Type 2 feedback. This paper studies both types of physical feedback in mesoscale cells of downward and upward FACs on the night side of the polar ionosphere from the data of two selected substorms of the summer and winter seasons in the northern hemisphere.
\end{abstract}

Key words: electric field and ionosphere conductivity; field-aligned currents; feedback; substorm; mesoscale cells

The article is published on the basis of the report made by the authors at the XII Russian-Mongolian International Conference

"Solar-Terrestrial Relations and Geodynamics of the Baikal-Mongolia Region" (October 1-5, 2018, Irkutsk)

RESEARCH ARTICLE

Received: February 12, 2019

Revised: March 27, 2019

Accepted: May 23, 2019

For citation: Mishin V.V., Lunyushkin S.B., Mishin V.M., Kurikalova M.A., Penskikh Yu.V., 2019. Estimation of the contributions of conductance and electric field to the intensity of field-aligned currents in the night polar ionosphere during substorm expansion phase. Geodynamics \& Tectonophysics 10 (3), 663-672. doi:10.5800/GT-2019-10-3-0433. 


\title{
ОЦЕНКА ВКЛАДОВ ПРОВОДИМОСТИ И ЭЛЕКТРИЧЕСКОГО ПОЛЯ В ИНТЕНСИВНОСТЬ ПРОДОЛЬНЫХ ТОКОВ В НОЧНОЙ ПОЛЯРНОЙ ИОНОСФЕРЕ ВО ВРЕМЯ ВЗРЫВНОЙ ФАЗЫ СУББУРИ
}

\author{
В. В. Мишин, С. Б. Лунюшкин, В. М. Мишин, \\ М. А. Курикалова, Ю. В. Пенских
}

\author{
Институт солнечно-земной физики СО РАН, Иркутск, Россия
}

\begin{abstract}
Аннотация: На основе выходных данных техники инверсии магнитограмм выполнен анализ динамики интенсивности ионосферных токов Педерсена и продольных токов в ночных мезомасштабных ячейках трех основных крупномасштабных зон (1, 2 и 0$)$ Ииджимы и Потемры во время взрывной фазы летней и зимней суббурь. Продольные токи играют ключевую роль в ионосферно-магнитосферном взаимодействии. Уравнение непрерывности плотности электрического тока содержит два типа возможной обратной связи на участках электрической цепи, соединяющих в каждой ячейке токи Педерсена и продольные токи. Ионосферная проводимость Педерсена является основной для Типа 1, а в обратной связи Типа 2 доминирует электрическое поле. В работе исследуются оба типа физической обратной связи в мезомасштабных ячейках втекающих и вытекающих продольных токов на ночной стороне полярной ионосферы по данным двух избранных суббурь летнего и зимнего сезонов в Северном полушарии.
\end{abstract}

Ключевые слова: электрическое поле и проводимость ионосферы; продольные токи; обратная связь; суббуря; мезомасштабные ячейки

\section{INTRODUCTION}

Investigation of the features of variations in the Earth magnetic field and causing them electric fields and currents in the atmosphere-ionosphere- magnetosphere system is an important component of not only geodynamics, but also of the space weather research, an actively developing discipline of solar-terrestrial physics in recent years. This paper studies contributions of the magnetospheric electric field and ionospheric conductivity to field-aligned currents (FACs), that flow along geomagnetic field lines and play a key role in the magnetosphere-ionosphere interaction [Kamide, Baumjohann, 1993]. Model of FAC distribution in the polar ionosphere [Iijima, Potemra, 1978; Potem$r a, 1978]$ was based on averaged satellite data. In this model, FACs of Region R0 are only in the daytime part of the polar cap, and the main large-scale FACs of Regions R1 and R2 are located in the auroral oval where they have the only FAC density maximum in each Region near the dawn - dusk meridian. We use the original version of magnetogram inversion technique (MITISTP) developed in ISTP SB RAS [Mishin, 1990]. Our MIT is based on the 1-minute data of ground-based geomagnetic measurements on the global network of stations and the dynamic model of ionospheric conductivity [Shirapov et al., 2000]. It provides calculations not only for 2D maps of electric potential distributions, in- tegral conductivities, horizontal currents and FACs, but also allows one to select and study inhomogeneous structures on these maps, which are termed 'mesoscale cells'. MIT gives a possibility to investigate localization and degree of influence of the electric field and / or conductivity of the ionosphere on the FAC intensity in space and time and relative to other geodynamic processes. In this paper, we study the dynamics of downward and upward FACs within large-scale FAC Regions R0, R1, and R2 (Fig. 1), according to the Iijima and Potemra (I-P) classification [Iijima, Potemra, 1978]. We focuse on FAC dynamics in the nighttime polar ionosphere, where the main processes of magnetic and auroral substorms are observed during the expansion phase (EP). The pair of downward R1+ and upward R1- FACs (flowing in R1+ and out of R1- cells, respectively) connects the EMF generator with the night auroral ionosphere. This generator is resulted from the magnetic reconnection in the near plasma sheet of the magnetospheric tail. It should be noted that the meridian separating the FAC cells of different signs may rotate clockwise from midnight to 18 MLT during the substorm (see Fig. 4 in [Mishin et al., 2017]). There are two possible closure schemes in the ionosphere of the main pair of FAC cells R1+ and R1-: the Pedersen meridional currents with the corresponding cells R2 and $\mathrm{R} 0$ and / or the azimuthal Pedersen current [Kurikalova et al., 2018, and references there]. In this 

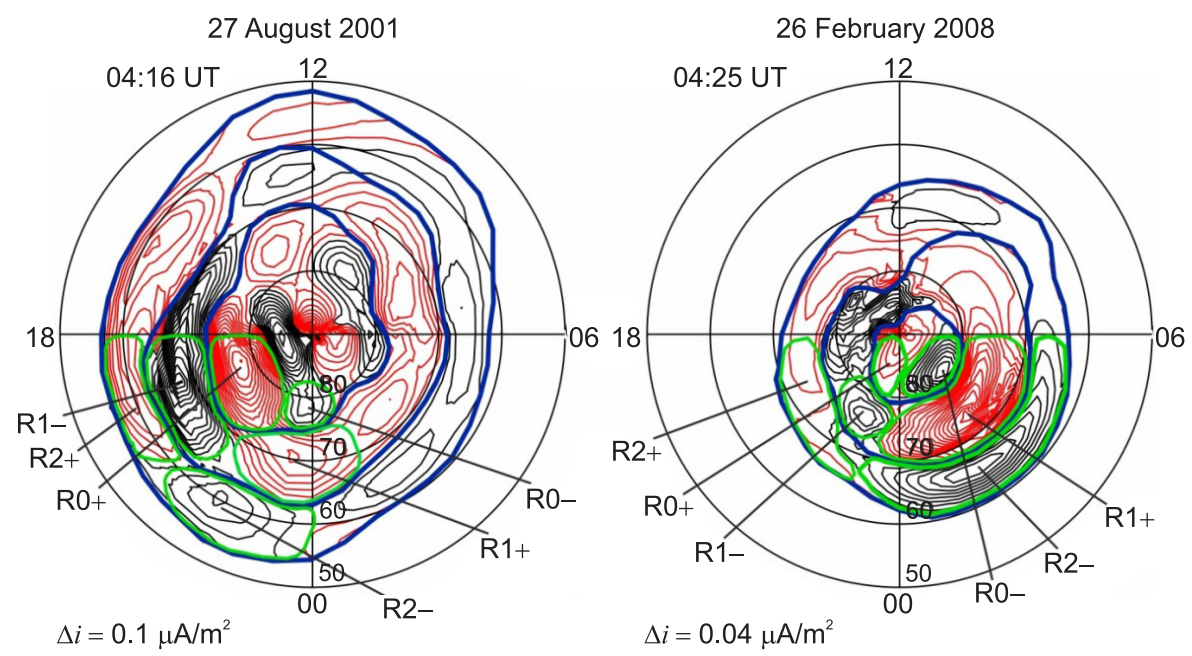

Fig. 1. FAC density distributions at the EP peak of the summer (left) and winter (right) substorms. Red isolines correspond to inflowing / downward FAC, black isolines - outflowing / upward FACs. Blue bold lines show the boundaries of the three large-scale regions R1, R2 and R0. Signs (+ / -) corresponds to downward / upward FACs respectively. Green lines - boundaries of mesoscale cells on the night side.

Рис. 1. Распределения плотности продольных токов (ПТ) на пике ЕР летней (слева) и зимней (справа) суббурь. Красные (черные) изолинии соответствуют втекающим (вытекающим) ПТ. Синие жирные линии - границы трех крупномасштабных зон R1, R2 и R0, а дополнительный знак плюс (минус) соответствует втекающему (вытекающему) ПТ в этих зонах. Зеленые линии - границы мезомасштабных ячеек на ночной стороне.

case, on the part of the electric circuit 'Pedersen currents - FACs', feedbacks may develop due to conductivity or electric field and regulate the ionospheremagnetosphere interaction [Atkinson, 1970; Mishin et al., 2013]. The available theoretical models of ionospheric feedback instabilities [Streltsov, Mishin, 2018, and references there], describe the excitation of smallscale FAC perturbations (scale $\geq 1 \mathrm{~km}$ ) with a small increase in their amplitude during a substorm in the region of discrete auroral arcs. However, during the substorm EP onset, increases in the FAC intensity on a large spatial scale $(>100 \mathrm{~km})$ are also observed, which are also characterized by a significant increase in the FAC intensity (by a factor of 2-3). The nature of such strong nonlinear feedbacks in the ionosphere-magnetosphere system is still poorly studied, and their further investigation is an urgent task for the physics of magnetospheric substorms. Our paper is aimed at solving this problem.

\section{DATABASE AND RESEARCH METHOD}

Using the 1-minute data of ground-based geomagnetic measurements of 110 magnetometers of the global network of the northern hemisphere stations and MITISTP [Mishin, 1990], we calculate the main electrodynamic parameters of the polar ionosphere and build the 2D maps of: electric potential U distributions, Pedersen and Hall conductivities, FAC densities, meridional $E_{\theta}$ and azimuthal $E_{\lambda}$ components of the electric field, and the corresponding components $j_{\theta}$ and $j_{\lambda}$ of the linear density of the horizontal ionospheric Hall and Pedersen currents. The EP intervals of two selected events are investigated: the (04:08-04:30) UT interval of the 27 August 2001 summer substorm and the (04:06-04:50) UT interval of the 26 February 2008 winter substorm. Fig. 1 shows examples of 2D FAC distribution maps. In our analysis, we use data of the IMF and solar wind parameters from [http://omniweb.gsfc.nasa.gov], and the geomagnetic activity indices $\mathrm{AE}$ and $\mathrm{AL}$, calculated by us from the data of the ground-based magnetometers used in the operation at latitudes $\Phi \geq 60^{\circ}$.

\subsection{MesosCale CELLS}

The 2D maps of FAC density distributions, obtained on the basis of the MIT every $1 \mathrm{~min}$, make it possible to determine not only the boundaries (blue bold lines in Fig. 1) of the large-scale FAC I-P Regions R1, R2, but also to select mesoscale cells inside these regions [Mishin et al., 2011]. Fig. 1 shows boundaries of cells by green lines. On FAC maps obtained using satellites [Iijima, Potemra, 1978; Potemra, 1978], mesoscale discontinuities are not visible due to statistical averaging. Each mesoscale cell on MIT maps is a local inhomogeneity of the FAC density distribution in the ionosphere, with a FAC density maximum in its center. These cells are located within each subzone (subregion) of the downward or upward FAC of Regions R1, R2 and R0. 
Next, we consider only night mesoscale cells that play a central role in the substorm EP development, because the FACs that flow through them provide the electric connection of the ionosphere (i.e. load) with the EMF generator in the near tail of the magnetosphere that was noted in the Introduction [Kepko et al., 2014]. In Fig. 1, the symbols $\mathrm{RM} \pm$ (where $\mathrm{M}=0,1$, or 2 ) denote the night cells of downward / upward FACs flowing into and out of the ionosphere (+ and -, respectively) in the corresponding I-P Regions R0, R1 and R2.

\subsection{CURRENT CONTINUITY EQUATION AND TWO TYPES OF FEEDBACK}

The equation of current density continuity in the MIT method is as follows:

$$
\operatorname{div}_{\perp}(\hat{\Sigma} \cdot \nabla U)=i \sin I
$$

where $\hat{\Sigma}$ is the integral ionospheric conductivity tensor; $\mathrm{U}$ is the electric potential; $i$ is the FAC density; $I$ is magnetic inclination; $d i v_{\perp}$ is a two-dimensional divergence operator. The simplest way to evaluate two feedback mechanisms in the magnetosphere-ionosphere (M-I) system is based on the fact that the divergence of the Hall ionosphere currents is near zero and FACs are closed in the ionosphere mainly by Pedersen currents [Sugiura, 1984]. Assuming at the same time that the Pedersen conductivity is homogeneous enough $\left(\nabla \Sigma_{P} \rightarrow 0\right)$ over a cell with area $S_{R M \pm}$, a simple estimated formula follows from equation (1):

$$
\Sigma_{P} \cdot \Delta U \cdot S \approx I_{R M \pm}
$$

where $\Sigma_{P}$ is the cell average Pedersen conductivity value, and $I_{R M \pm}$ is the FAC intensity in the corresponding cell RM \pm . In the study of the FAC dynamics in the cells R1- and R0+, we use formula (2), with $I_{R 1-}$ or $I_{R 0+}$ at the right side respectively.

From formula (2), it follows that in the M-I system, a positive feedback between the changes of $\Sigma_{P}$ and $I_{R 1-}$ and the corresponding instability can develop during the summer substorm EP in the northern hemisphere in the FAC cell R1- located in the premidnight sector. The development of such a positive feedback or Type 1 instability is considered as a "short circuit" associated with a sharp increase in conductivity since the EP onset. The upward R1- FAC is transported by precipitating energetic electrons, which are also an ionization source that increases the ionosphere conductivity [e.g. Atkinson, 1970; Mishin et al., 2013; Korth et al., 2014].

Formula (2) also allows feedback between the current $I_{R 0+}$ and the electric field in the R0+ cell, in which the downward FAC is mainly transported by thermal electrons going up from the ionosphere, which reduces the conductivity and thereby increases the electric field. The development of such feedback and Type 2 instability is also possible in the R1+ cell in the premidnight sector during the winter substorm EP in the northern hemisphere. The theoretical model for the development of small-scale ionospheric feedback instability under such initial conditions explains the dynamics of discrete auroras during substorms [Trakhtengertz, Feldstein, 1984; Streltsov, Mishin, 2018].

\section{ANALYSIS OF FEEDBACKS IN THE IONOSPHERE- MAGNETOSPHERE SYSTEM}

\subsection{The 27 AUGUST 2001 SUBSTORM}

For two substorms recorded on 27 August 2001 and 26 February 2008, Figure 2 shows graphs of changes in the following parameters: solar wind dynamic pressure $\left(P_{d}\right)$; interplanetary magnetic field (IMF) components $\left(B_{z}, B_{y}\right.$ and $\left.B_{x}\right)$; auroral indices of geomagnetic activity ( $A E$ and $A L$ ); potential differences across the polar cap $U_{P C}$, and the variable part of the open magnetic flux of tail lobes $\Psi_{1}$. The variable part of the magnetic flux $\Psi_{1}=\Psi-\Psi_{0}$ is a difference between the total polar cap magnetic flux $\Psi$ and its presubstorm value $\Psi_{0}$. The total flux is $\Psi=\iint_{S} \boldsymbol{B} \cdot d \boldsymbol{S}$, where $\boldsymbol{B}(\boldsymbol{r})$ is the dipolar geomagnetic field at $115 \mathrm{~km}$ and $\mathrm{S}$ is the polar cap (R0) area. The left column in Fig. 2 clearly shows that the summer substorm EP on 27 August 2001 began at $\sim 04: 08$ UT after the turn of the IMF $B_{z}$ to the north. The EP onset is characterized by a sharp decrease in the magnetic flux $\Psi$ and a rapid increase in the $\mathrm{AE}$ index. This substorm EP is assumed to end at $\sim 04: 35$ UT when the $\Psi$ flux decline slowed down and the AE index and the $U_{P C}$ cross polar cap potential decreased (see also [Mishin et al., 2011, 2015]).

According to [Mishin et al., 2013], at the EP onset of the 27 August 2001 substorm, the FAC intensity in the evening sector nonlinearly increased in all three zones, and in the R0+ cell it was more than twice as high as in the R2+ cell. Since the upward FAC of the R1- cell is transported by precipitating electrons, Mishin et al. explained these findings by a 'short-circuit', the physical phenomenon well-known from electrical engineering. In the ionosphere, this means the development of positive feedback between the rapidly growing upward FAC R1- and the simultaneous increase in the ionospheric conductivity created by the same electrons that transport the upward FAC R1-. It is also known that the power supply of ionospheric currents inside the auroral bulge is largely provided by the Region 0 FAC [Kepko et al., 2014].

Based on the above, we attempted in this work to separate the contributions of two variable parameters, conductivity and electric field, to changes in the FAC intensity in the night cells R1- and R0+. Using MIT 
27 Aug 2001
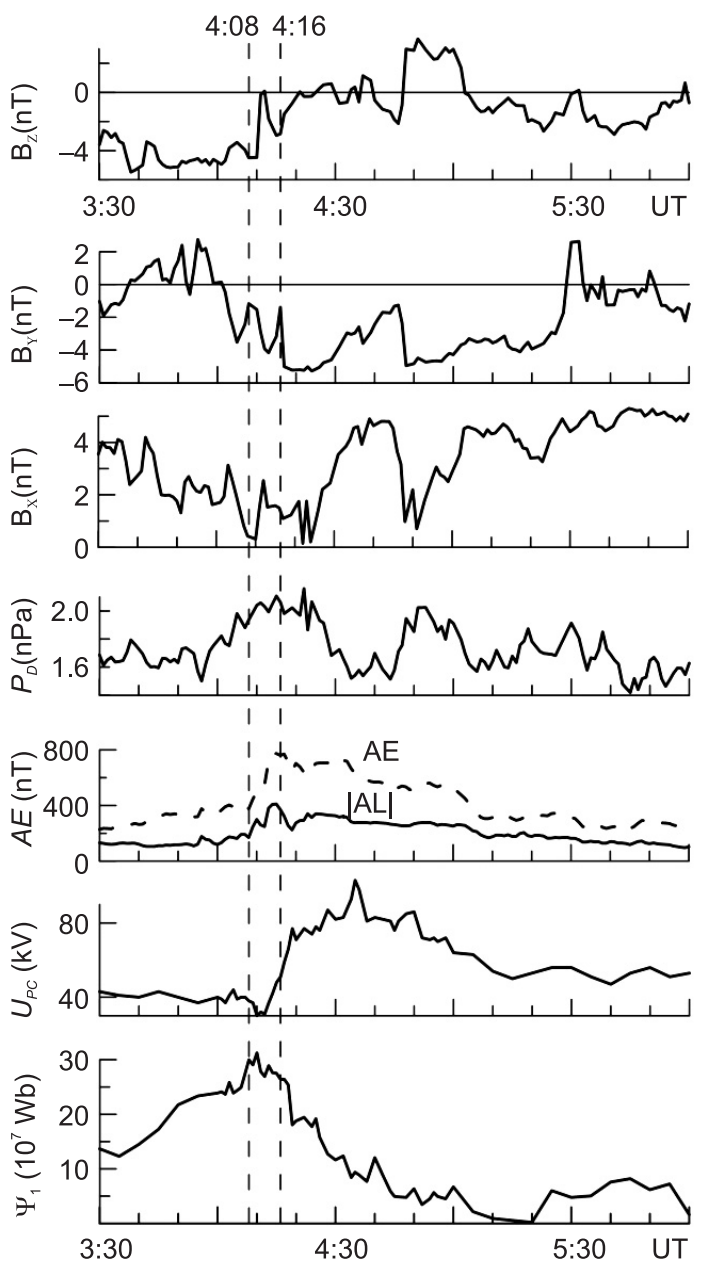
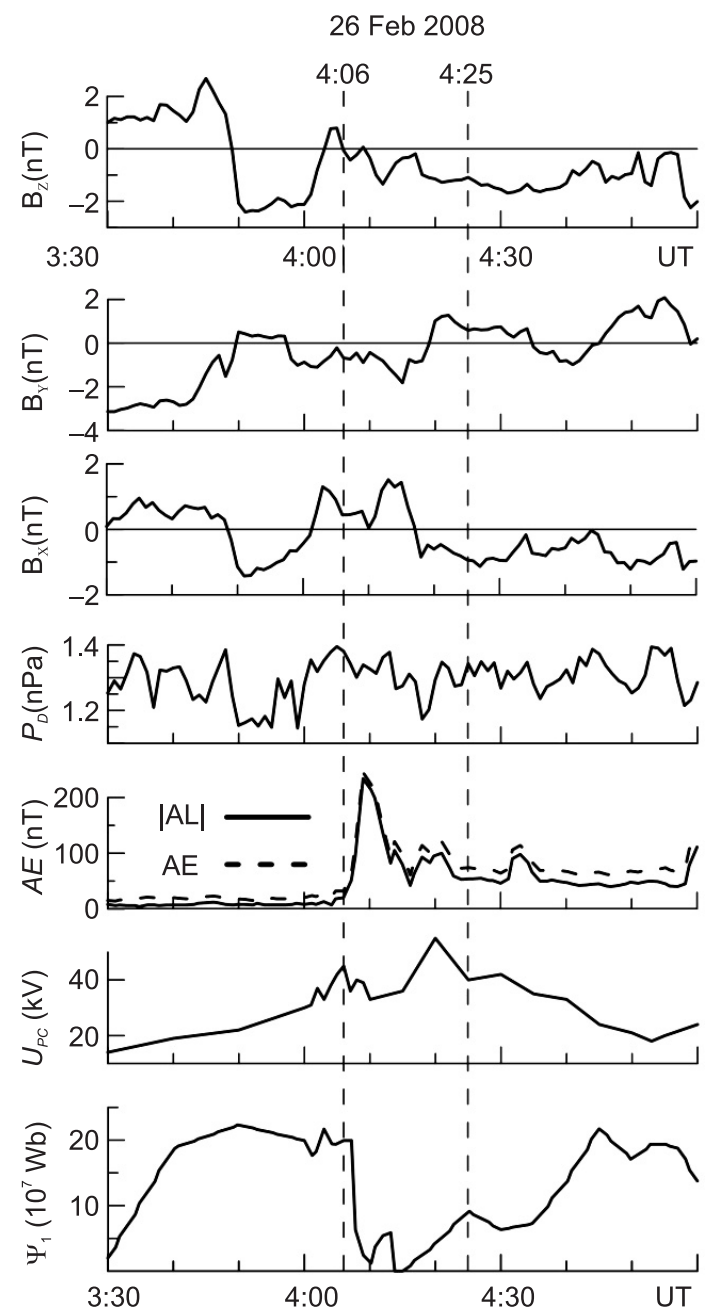

Fig. 2. Variations in the main geophysical parameters during the summer (27 August 2001 - left) and winter (26 February 2008 - right) substorms in the northern hemisphere. Top to bottom: variations of the IMF components $B_{z}, B_{y}, B_{x}$; solar wind dynamic pressure $\left(P_{d}\right)$; indices of auroral activity $(A E, A L)$; potential differences across the polar cap $\left(U_{P C}\right)$ and open magnetic flux $\left(\Psi_{1}\right)$.

Рис. 2. Графики изменения основных геофизических параметров в ходе развития летней (27 Aug 2001 - слева) и зимней (26 Feb 2008 - справа) суббурь в Северном полушарии. Сверху вниз показаны: вариации компонент ММП В $\mathrm{B}_{\mathrm{y}}, \mathrm{B}_{\mathrm{x}}$; динамического давления солнечного ветра $\left(P_{d}\right)$; индексов авроральной активности $(\mathrm{AE}, \mathrm{AL}) ; \mathrm{pazноcти} \mathrm{потен-}$ циалов поперек полярной шапки $\left(U_{P C}\right)$ и открытого магнитного потока $\left(\Psi_{1}\right)$.

capabilities, we calculated (with a step of $1 \mathrm{~min}$ ) FAC intensities in the selected cells R1- and R0+ in two variants: (1) in the approximation of homogeneous ionospheric conductivity, when $I_{R M \pm}=I_{R M \pm}(E)$, i.e. the FAC intensity depends only on the electric field of the magnetospheric EMF source (red curve in Fig. 3); and (2) with inhomogeneous conductivity, when the FAC intensity $I_{R M \pm}=I_{R M \pm}(E, \Sigma)$ is a function of both parameters (black curve in Fig. 3). A simple estimate of the contribution of conductivity inhomogeneity to the FAC intensity was obtained from the calculation of the difference $I_{R M \pm}(\Sigma)=I_{R M \pm}(E, \Sigma)-I_{R M \pm}(E)$ in the selected cells (blue curves in Fig. 3). Figures $3 \mathrm{c}$ and $3 \mathrm{~d}$ also show graphs of the relative contributions of the electric field $I_{R M \pm}(E) / I_{R M \pm}$ (red curve) and conductivi- ty $I_{R M \pm}(\Sigma) / I_{R M \pm}$ (blue curve) in the FAC intensity in the selected cells during the substorm EP on 27 August 2001 . The results of the described calculations are presented in the form of graphs in Fig. 3: on the left - for the R0+ cell, on the right - for the R1- cell. All three curves in Fig. 3 show a synchronous enough change during the substorm EP with maximum near the EP peak. However, there are differences in the behavior of the red and blue curves in the left and right columns (Fig. 3).

At the growth phase (until 04:08 UT), the red and blue curves in Fig. 3, a, practically merge, i.e. contributions of the conductivity inhomogeneity and electric field are comparable. However, from 04:08 UT during EP, the red curve becomes noticeably higher 


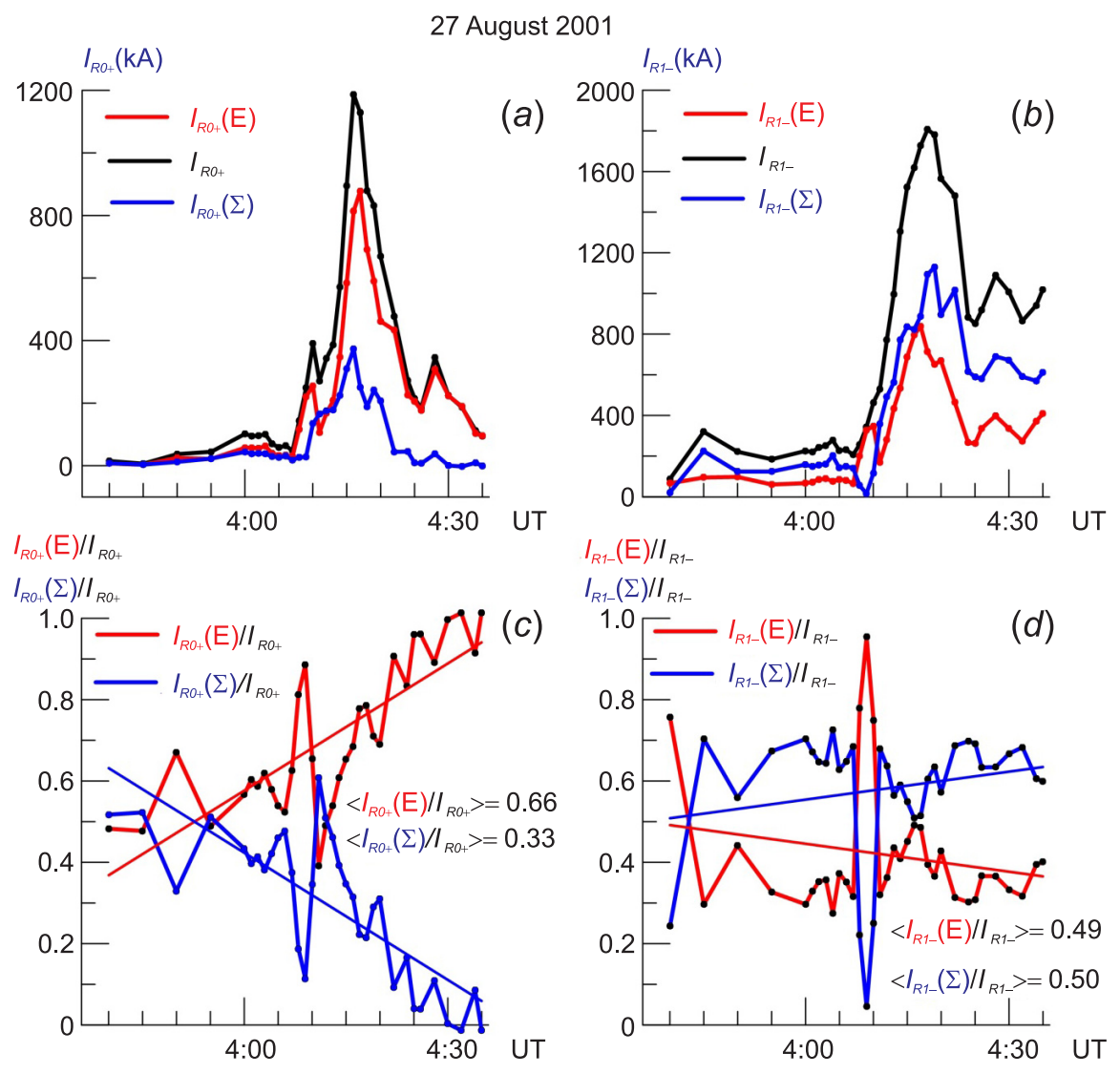

Fig. 3. Changes of FAC intensities in the night cells of the premidnight sector R0+ (left) and R1- (right). The black curve (top panel) is the FAC intensity calculated using the inhomogeneous ionosphere conductivity model, when $I_{R M \pm}=I_{R M \pm}(E, \Sigma)$. The red curve is the FAC intensity calculated in the homogeneous conductivity model, when $I_{R M_{ \pm}}=I_{R M \pm}(E)$. The blue curve (top panel) shows the difference $I_{R M \pm}(\Sigma)=I_{R M \pm}(E, \Sigma)-I_{R M \pm}(E)$, which gives an approximate estimate of the contribution of conductivity inhomogeneity (as the ionospheric source) to the FAC intensity. The bottom panel shows graphs illustrating the relative contributions of the electric field $I_{R M \pm}(E) / I_{R M \pm}(E, \Sigma)$ (red curve) and conductivity $I_{R M \pm}(\Sigma) / I_{R M \pm}(E, \Sigma)($ blue curve) in the FAC intensity; their mean values over the entire substorm interval are indicated.

Рис. 3. Графики изменения интенсивностей Пт в ночных ячейках предполуночного сектора R0+ (слева) и R1(справа) в ходе летней суббури 27 августа 2001 г. Черная кривая (верхняя панель) - интенсивность ПТ, рассчитанных с использованием модели неоднородной проводимости ионосферы, когда $I_{R M \pm}=I_{R M \pm}(E, \Sigma)$. Красная кривая интенсивность ПТ, рассчитанных в варианте однородной проводимости, когда $I_{R M \pm}(E)$. Синяя кривая (верхняя панель) показывает разность $I_{R M \pm}(\Sigma)=I_{R M \pm}(E, \Sigma)-I_{R M \pm}(E)$, которая дает примерную оценку вклада неоднородности проводимости (как ионосферного источника) в интенсивность ПТ. На нижней панели даны графики, иллюстрирующие относительный вклад электрического поля $I_{R M \pm}(E) / I_{R M \pm}\left(\right.$ красная кривая) и проводимости $I_{R M \pm}(\Sigma) / I_{R M \pm}$ (синяя кривая) в интенсивность ПТ; указаны их средние значения по всему интервалу суббури.

than the blue one. Fig. 3, c, illustrates the dynamics of the relative contributions of the electric field $I_{R M \pm}(E) / I_{R M \pm}(E, \Sigma)$ (red curve) and conductivity $I_{R M \pm}(\Sigma) / I_{R M \pm}(E, \Sigma)$ (blue curve) in the FAC intensity $I_{R M \pm}=I_{R M \pm}(E, \Sigma)$. The discrepancy between the curves was small before the EP. However, it rapidly increased after the EP onset, which means an increase in the relative contribution of the electric field and at the same time a decrease in the relative contribution of conductivity to the FAC intensity $I_{R 0+}$ in the R0+ cell. All of the above means that the contribution of the conductivity inhomogeneity becomes small, and the contribution of the electric field prevails in the $I_{R 0+}$ FAC.
The opposite picture is observed in the FAC cell R1-. For the most part of the considered interval of the late growth phase and the EP (with the exception of the short interval near the EP onset and its peak), the blue curve lies above the red one (Fig. $3, b$ ). It means that the contribution of the ionosphere conductivity inhomogeneity to the $I_{R 1-}$ intensity variations exceeds the contribution determined by the change in the electric field. One can see that the absolute value of the difference between the curves of the relative values of the contributions of the electric field $I_{R M \pm}(E) / I_{R M \pm}$ (red curve) and conductivity $I_{R M \pm}(\Sigma) / I_{R M \pm}$ in Fig. 3, $d$, is noticeably smaller than that in Fig. $3, c$, i.e. the role 


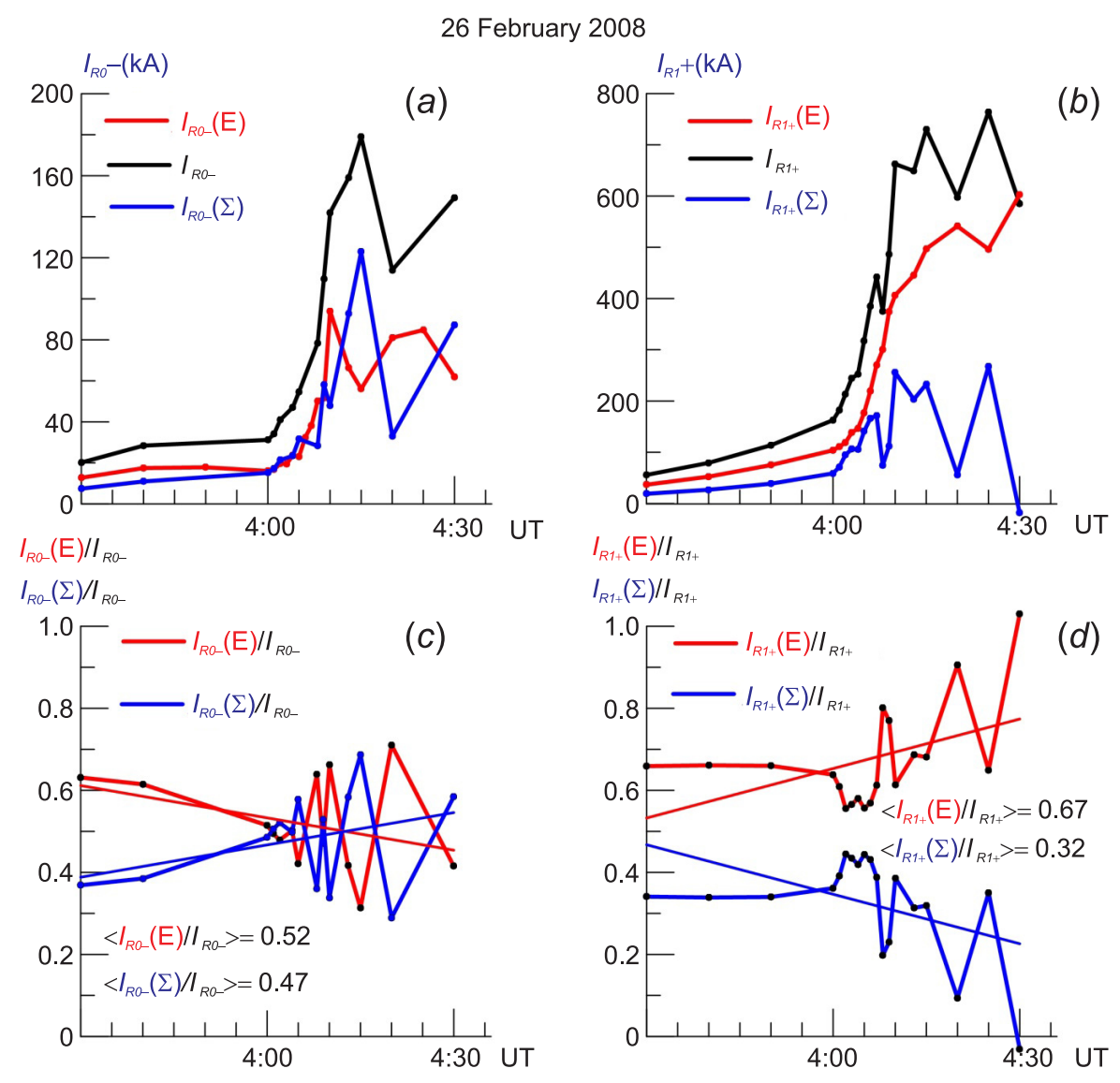

Fig. 4. The graphs of the FAC intensity changes in the night cells R0- (left) and R1+ (right) of the premidnight sector during the 26 February 2008 winter substorm. All the notations are the same as in Fig. 3.

Рис. 4. Графики изменения интенсивности ПТ в ночных ячейках R0- (слева) и R1+ (справа) предполуночного сектора в ходе зимней суббури 26 февраля 2008 г. Все обозначения те же, что и на рис. 3.

of conductivity inhomogeneity is noticeably stronger in the cell R1- of the upward FAC.

So, our analysis shows that during the summer substorm EP in the cell $\mathrm{R0+}$, there is a noticeable predominance of the electric field contribution to the intensity $I_{R 0+}$ of the downward FAC compared to the influence of the ionospheric conductivity in this cell. And vice versa, we found that in the R1- upward FAC cell, the contribution of the conductivity inhomogeneity to the FAC intensity $I_{R 1-}$ prevails over the electric field contribution.

We also note the presence of a feature common to both of the considered cells at the EP onset 104:0704:11 UT) - a sharp jump in the red curve upwards (current dependence on the electric field) simultaneously with a jump in the blue curve downwards (current dependence on conductivity), which is clearly visible in the graphs of the lower panel in Fig. 3.

\subsection{THE 26 FEBRUARY 2008 SUBSTORM}

The 26 February 2008 winter substorm compared to the above considered summer substorm was less intense: the maximum value of the $\mathrm{AE}$ index was $\sim 250 \mathrm{nT}$ (see Fig. 2), which is 3 times less than at the peak of the summer substorm. The EP of the winter substorm began at 04:06 UT shortly after the rotation of the IMF $B_{Z}$ component to the north, which caused the beginning of a rapid decrease in the open magnetic flux of the tail lobes $\Psi_{1}$ and the $\mathrm{AE}$ index rapid growth (see Fig. 2). A characteristic feature of this winter substorm is a sharp decrease in the intensity of all the FACs in the evening sector (see Fig. 1) during EP. Let us further consider the FAC dynamics in the mesoscale cells R1+ and $\mathrm{R} 0$ - in the premidnight sector.

The calculated contributions of the electric field and conductivity in the FAC intensity in the cells R1+ and R0- are shown in Fig. 4, similar to Fig. 3. One can see that (as in the case of the summer substorm) in the cell of the downward FAC R1+ during the entire interval of the winter substorm, including the second half of its growth phase and EP, a change in the electric field creates the main contribution to the growth of the FAC intensity $I_{R 1+}$ (Fig. 4, b), and the relative contribution of conductivity to the change in $I_{R 1+}$ also decreases markedly during the EP (Fig. 4, $d$ ). 
In the cell R0-, the contribution to the growth of the FAC intensity $I_{R 0_{-}}$, determined by conductivity, is weak during the growth phase, but it increases during EP. On average, throughout the substorm, it is comparable with the contribution of the electric field (Fig. 4, a). However, as in the upward R1- FAC cell during the summer substorm EP, in the R0- cell, near the maximum of the winter substorm EP, the blue curve becomes twice higher, that demonstrates the dominant contribution of the ionospheric conductivity to the $I_{R 0-}$

FAC intensity (Fig. 4, c).

\section{DISCUSSION}

The general SCW model [Fujii et al., 1994; Gjerloev, Hoffman, 2000a, 2000b, 2002] shows that the power supply of ionospheric electric currents within the auroral bulge is largely provided by the Region 0 FAC, located northward of the upper auroral bulge boundary. Kurikalova et al. [2018] showed that the main part of the FAC closure occurs in the meridional direction between the downward Region 0 FAC and the upward Region 1 FAC, which are in the auroral bulge. Kepko et al. [2014] suggested that the Region 0 FAC can be the result of a large conductivity gradient and the corresponding polarization electric field at the auroral bulge edge.

Our present study of the 27 August 2001 substorm, reveals a high correlation between changes in the meridional component of the electric field and the downward FAC intensity in the premidnight cell R0. Thus, one can conclude that the evening cell R0+ during this summer substorm is mainly controlled by the magnetospheric electric field.

FACs are transported by both electrons and ions. Magnetospheric electrons dominate in the transport of upward FACs, and ionospheric thermal electrons - in the transport of downward FACs [Cattell et al., 1979]. Lu et al. [2000] showed that large-scale upward FACs obtained by the AMIE method, in general, coincide with relatively intense auroral UV emissions in the central auroral oval. Therefore, one can expect a positive feedback between the FAC intensity and the ionosphere conductivity in the FAC R1- area in the evening sector. From our study results for the summer 27 August 2001 substorm, it follows that the change in the FAC intensity, related to conductivity, exceeds the change determined by the electric field variations. However, precipitating electrons transporting upward FACs can be accelerated by a parallel electric field [Evans, 1974; Mozer et al., 1980]. Perhaps this is the reason that the contributions of the electric field and conductivity to the FAC intensity in this region are comparable.

The FAC flowing into the R1+ premidnight cell here connects the auroral ionosphere with the magneto- spheric generator [Mishin et al., 2015]. Our study results for the winter 26 February 2008 substorm show that during EP in the cell R1+ the average relative value of the electric field contribution to the FAC intensity was twice as large as the average relative value of the conductivity contribution.

\section{CONCLUSION}

The analysis of the FACs dynamics in the selected mesoscale cells during the expansion phase (EP) of the 27 August 2001 and 26 February 2008 substorms, allows us to draw the following conclusions.

1. The positive feedback between the FAC intensity and the electric field is observed in night cells of downward FACs: in the evening mesoscale R0+ cell during the summer substorm; and in the morning mesoscale cell R1+ during the winter substorm. In both these cells, the change in the FAC intensity is determined mainly by the electric field.

2. During the summer substorm EP in the evening mesoscale R1- cell of the upward FAC, the contribution of conductivity to changes in the FAC intensity exceeds the contribution of the electric field. During the winter substorm EP in the morning mesoscale cell R0-, the contributions of conductivity and electric field to FAC changes are generally comparable, but at the EP peak, the contribution of conductivity prevails.

The results of this study of the two substorms generally confirm our initial assumptions about the physical mechanism of two types of positive feedback: Type 1 between the FAC intensity and the electric field in the downward FAC cells; Type 2 - between the FAC intensity and the conductivity in the upward FAC cells. These conclusions refer to only two isolated substorms and, therefore, are preliminary and providing a good starting point for discussion. Further research is needed to develop and confirm these initial findings.

\section{ACKNOWLEDGEMENTS}

Experimental data were obtained using the equipment of Center for Common Use 692 'Angara' (http://ckp-rf.ru/ckp/3056/), solar wind parameters and geomagnetic indices from OMNIWeb (https:// omniweb.gsfc.nasa.gov/) and WDC-Kyoto (http://wdc. kugi.kyoto-u.ac.jp/index.html), 1-min geomagnetic data from the international projects CARISMA, INTERMAGNET, GIMA, MACCS, IMAGE. We are thankful to heads of magnetic observatories O.A. Troshichev (AARI), E.P. Kharin (IDC_B), B.M. Shevtsov, and A.V. Vinnitsky (IKIR FEB RAS), D.G. Baishev (IKFIA SB RAS), S. Khomutov (Novosibirsk observatory), O. Kusonsky (Arti observatory), and Danish Meteorological 
Institute. The work was performed with budgetary funding of Basic Research Program II.16 and partially supported by the Russian Foundation for Basic Research (Grant No 18-05-00437).

\section{REFERENCES}

Atkinson G., 1970. Auroral arcs: Result of the interaction of a dynamic magnetosphere with the ionosphere. Journal of Geophysical Research 75 (25), 4746-4755. https://doi.org/10.1029/JA075i025p04746.

Cattell C., Lysak R., Torbert R.B., Mozer F.S., 1979. Observations of differences between regions of current flowing into and out of the ionosphere. Geophysical Research Letters 6 (7), 621-624. https://doi.org/10.1029/GL006i007 p00621.

Evans D.S., 1974. Precipitating electron fluxes formed by a magnetic field aligned potential difference. Journal of Geophysical Research 79 (19), 2853-2858. https://doi.org/10.1029/JA079i019p02853.

Fujii R., Hoffman R.A., Anderson P.C., Craven J.D., Sugiura M., Frank L.A., Maynard N.C., 1994. Electrodynamic parameters in the nighttime sector during auroral substorms. Journal of Geophysical Research: Space Physics 99 (A4), 6093-6112. https://doi.org/10.1029/93ja02210.

Gjerloev J.W., Hoffman R.A., 2000a. Height-integrated conductivity in auroral substorms: 1. Data. Journal of Geophysical Research: Space Physics 105 (A1), 215-226. https://doi.org/10.1029/1999ja900354.

Gjerloev J.W., Hoffman R.A., 2000b. Height-integrated conductivity in auroral substorms: 2. Modeling. Journal of Geophysical Research: Space Physics 105 (A1), 227-235. https://doi.org/10.1029/1999ja900353.

Gjerloev J.W., Hoffman R.A., 2002. Currents in auroral substorms. Journal of Geophysical Research: Space Physics 107 (A8), 1163. https://doi.org/10.1029/2001ja000194.

Iijima T., Potemra T.A., 1978. Large-scale characteristics of field-aligned currents associated with substorms. Journal of Geophysical Research: Space Physics 83 (A2), 599-615. https://doi.org/10.1029/JA083iA02p00599.

Kamide Y., Baumjohann W., 1993. Magnetosphere-Ionosphere Coupling. Springer, Berlin, 178 p. https://doi.org/ 10.1007/978-3-642-50062-6.

Kepko L., McPherron R.L., Amm O., Apatenkov S., Baumjohann W., Birn J., Lester M., Nakamura R., Pulkkinen T.I., Sergeev V., 2014. Substorm current wedge revisited. Space Science Reviews 190 (1-4), 1-46. https://doi.org/10.1007/ s11214-014-0124-9.

Korth H., Zhang Y., Anderson B.J., Sotirelis T., Waters C.L., 2014. Statistical relationship between large-scale upward field-aligned currents and electron precipitation. Journal of Geophysical Research: Space Physics 119 (8), 6715-6731. https://doi.org/10.1002/2014ja019961.

Kurikalova M.A., Mishin V.M., Mishin V.V., Lunyushkin S.B., Penskikh Y.V., 2018. Relative role of the azimuthal Pedersen current component in the substorm global electric circuit. Journal of Atmospheric and Solar-Terrestrial Physics 179, 562-568. https://doi.org/10.1016/j.jastp.2018.09.014.

Lu G., Brittnacher M., Parks G., Lummerzheim D., 2000. On the magnetospheric source regions of substormrelated field-aligned currents and auroral precipitation. Journal of Geophysical Research: Space Physics 105 (A8), 18483-18493. https://doi.org/10.1029/1999ja000365.

Mishin V.M., 1990. The magnetogram inversion technique and some applications. Space Science Reviews 53 (1-2), 83-163. https://doi.org/10.1007/bf00217429.

Mishin V.M., Förster M., Kurikalova M.A., Mishin V.V., 2011. The generator system of field-aligned currents during the April 06, 2000, superstorm. Advances in Space Research 48 (7), 1172-1183. https://doi.org/10.1016/j.asr.2011. 05.029.

Mishin V.M., Kurikalova M.A., Mishin V.V., Wang C., Wang J.Y., 2015. Field-aligned current dynamics in two selected intervals of the 6 April 2000 superstorm. In: A.G. Yahnin (Ed.), Physics of auroral phenomena. Proceedings of the XXXVIII Annual Seminar. Kola Science Centre, Russian Academy of Science, Apatity, p. 24-27.

Mishin V.M., Mishin V.V., Lunyushkin S.B., Wang J.Y., Moiseev A.V., 2017. 27 August 2001 substorm: Preonset phenomena, two main onsets, field-aligned current systems, and plasma flow channels in the ionosphere and in the magnetosphere. Journal of Geophysical Research: Space Physics 122 (5), 4988-5007. https://doi.org/10.1002/2017 ja023915.

Mishin V.M., Pu Z., Mishin V.V., Lunyushkin S.B., 2013. Short-circuit in the magnetosphere-ionosphere electric circuit. Geomagnetism and Aeronomy 53 (6), 809-811. https://doi.org/10.1134/s001679321306008x.

Mozer F.S., Cattell C.A., Hudson M.K., Lysak R.L., Temerin M., Torbert R.B., 1980. Satellite measurements and theories of low altitude auroral particle acceleration. Space Science Reviews 27 (2), 155-213. https://doi.org/10.1007/ BF00212238.

Potemra T.A., 1978. Observation of Birkeland currents with the TRIAD satellite. Astrophysics and Space Science 58 (1), 207-226. https://doi.org/10.1007/bf00645387.

Shirapov D.S., Mishin V.M., Bazarzhapov A.D., Saifudinova T.I., 2000. Adapted dynamic model of ionospheric conductivity. Geomagnetism and Aeronomy 40 (4), 471-475. 
V.V. Mishin et al.: Estimation of the contributions of conductance and electric field to the intensity of field-aligned currents...

Streltsov A.V., Mishin E.V., 2018. On the existence of ionospheric feedback instability in the Earth's magnetosphere-ionosphere system. Journal of Geophysical Research: Space Physics 123 (11), 8951-8957. https://doi.org/ 10.1029/2018JA025942.

Sugiura M., 1984. A fundamental magnetosphere-ionosphere coupling mode involving field-aligned currents as deduced from DE-2 observations. Geophysical Research Letters 11 (9), 877-880. https://doi.org/10.1029/ GL011i009p00877.

Trakhtengertz V.Y., Feldstein A.Y., 1984. Quiet auroral arcs: Ionosphere effect of magnetospheric convection stratification. Planetary and Space Science 32 (2), 127-134. https://doi.org/10.1016/0032-0633(84)90147-8.

\section{Vladimir V. Mishin}

Doctor of Physics and Mathematics

Institute of Solar-Terrestrial Physics, Siberian Branch of RAS

126A Lermontov street, Irkutsk 664033, Russia

凶e-mail: vladm@iszf.irk.ru

(iD) https://orcid.org/0000-0002-2729-2862

\section{Sergei B. Lunyushkin}

Institute of Solar-Terrestrial Physics, Siberian Branch of RAS

126A Lermontov street, Irkutsk 664033, Russia

e-mail: Lunyushkin@iszf.irk.ru

(iD) https://orcid.org/0000-0003-0474-1079

\section{Vilen M. Mishin}

Doctor of Physics and Mathematics

Institute of Solar-Terrestrial Physics, Siberian Branch of RAS

126A Lermontov street, Irkutsk 664033, Russia

e-mail: mishin@iszf.irk.ru

(iD) https://orcid.org/0000-0001-7782-2107

Marina A. Kurikalova

Candidate of Physics and Mathematics

Institute of Solar-Terrestrial Physics, Siberian Branch of RAS

126A Lermontov street, Irkutsk 664033, Russia

e-mail: kurikalova@iszf.irk.ru

(iD) https://orcid.org/0000-0002-0710-8917

\section{Yuri V. Penskikh}

Institute of Solar-Terrestrial Physics, Siberian Branch of RAS

126A Lermontov street, Irkutsk 664033, Russia

e-mail: penskikh@iszf.irk.ru

(iD) https://orcid.org/0000-0002-5298-6487

\section{Владимир Виленович Мишин}

докт. физ.-мат. наук

Институт солнечно-земной физики СО РАН

664033, Иркутск, ул. Лермонтова, 126А, Россия

\section{Сергей Брониславович Лунюшкин}

Институт солнечно-земной физики СО РАН 664033, Иркутск, ул. Лермонтова, 126А, Россия

\section{Вилен Моисеевич Мишин \\ докт. физ.-мат. наук}

Институт солнечно-земной физики СО РАН 664033, Иркутск, ул. Лермонтова, 126А, Россия

\section{Марина Александровна Курикалова}

канд. физ.-мат. наук

Институт солнечно-земной физики СО РАН 664033, Иркутск, ул. Лермонтова, 126А, Россия

\section{Юрий Владимирович Пенских}

Институт солнечно-земной физики СО РАН 664033, Иркутск, ул. Лермонтова, 126А, Россия 